\title{
Reductions in US life expectancy from COVID-19 by Race and Ethnicity: Is 2021 a repetition of 2020 ?
}

\author{
Updated March 7, 2022 \\ Theresa Andrasfay, Ph.D. ${ }^{\text {a }}$ \\ Noreen Goldman, D.Sc. ${ }^{\text {b }}$

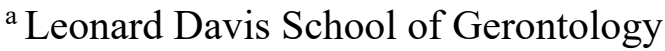 \\ University of Southern California \\ ${ }^{\mathrm{b}}$ Office of Population Research \\ School of Public and International Affairs \\ Princeton University
}

Corresponding Author: Theresa Andrasfay (andrasfa@usc.edu) 
medRxiv preprint doi: https://doi.org/10.1101/2021.10.17.21265117; this version posted March 7, 2022. The copyright holder for this preprint (which was not certified by peer review) is the author/funder, who has granted medRxiv a license to display the preprint in perpetuity.

It is made available under a CC-BY 4.0 International license.

\begin{abstract}
COVID-19 had a huge mortality impact in the US in 2020 and accounted for most of the overall reduction in 2020 life expectancy at birth. There were also extensive racial/ethnic disparities in the mortality impact of COVID-19 in 2020, with the Black and Latino populations experiencing reductions in life expectancy at birth over twice that of the White population. Despite continued vulnerability of the Black and Latino populations, the hope was that widespread distribution of effective vaccines would mitigate the overall impact and reduce racial/ethnic disparities in 2021. In this study, we use cause-deleted life table methods to quantify the impact of COVID-19 mortality on 2021 US period life expectancy. Our estimates, based on provisional COVID-19 deaths for 2021, indicate that racial/ethnic disparities have persisted and that COVID-19 deaths resulted in a decline in life expectancy at birth in 2021 of 1.7 years from pre-pandemic levels, 0.4 years more than estimated for 2020. The corresponding reductions estimated for the Black and Latino populations are 1.4-2 times that for Whites, suggesting smaller disparities than those in 2020. However, this narrowing is almost entirely the result of a large increase in COVID-19 mortality among Whites in 2021, in contrast to relatively constant reductions for the Black and Latino populations in the two years. Estimated declines in life expectancy at age 65 increased slightly for Whites between 2020 and 2021 but decreased for both the Black and Latino populations, resulting in the same overall reduction (1.1 years) estimated for 2020 and 2021.
\end{abstract}


medRxiv preprint doi: https://doi.org/10.1101/2021.10.17.21265117; this version posted March 7, 2022. The copyright holder for this preprint (which was not certified by peer review) is the author/funder, who has granted medRxiv a license to display the preprint in perpetuity.

It is made available under a CC-BY 4.0 International license .

\section{Introduction}

The staggering death toll in the US from COVID-19 has been well-documented: deaths attributed to COVID-19 in 2020 account for most of the 1.8-year reduction in period life expectancy at birth, reversing over 18 years of progress in mortality improvement $(1,2)$. In a previous paper, we predicted that widespread availability of an effective vaccine would lessen the impact of COVID-19 on 2021 life expectancy compared with 2020, although life expectancy was unlikely to return to pre-pandemic levels (3). Several highly effective vaccines have indeed been developed in record time, but relatively low vaccine coverage in the US, combined with the highly transmissible Delta and Omicron variants of SARS-CoV-2, have led to additional mortality surges, and, by the end of 2021, the total number of COVID-19 deaths had exceeded the 2020 total by $30 \%$ (4-6). These sobering numbers combined with the younger age distribution of deaths in 2021 (see Figure 1) - resulting partly from higher vaccination rates among older individuals - indicate that the impact of COVID-19 on US life expectancy in 2021 will be larger than that in the preceding year.

The disproportionate impact of COVID-19 on the survival of vulnerable populations has also received extensive attention: the Latino and Black populations experienced declines in life expectancy over twice as large as that for Whites (1). Risk factors for COVID-19 infection and mortality, such as crowded living conditions, frontline jobs with high exposure to infection and low pay, dependence on public transportation, low access to quality healthcare, and high rates of select chronic conditions, still characterize these groups, suggesting continued racial/ethnic disparities in COVID-19 mortality (7-11). A strategically-targeted vaccine distribution had the potential to reduce racial/ethnic disparities in COVID-19 mortality in 2021 (12), but many individuals faced barriers to vaccination in the early months, including difficulty scheduling vaccine appointments online, lack of transportation to vaccination sites, and lack of time off work to get vaccinated and recover from side effects $(13,14)$. The resulting inequitable vaccine distribution and uptake may have further exacerbated racial/ethnic disparities in COVID-19 mortality. However, as vaccines became more widely available in the later months of 2021, racial/ethnic differentials in vaccination rates decreased $(15,16)$. By August 2021, differences in vaccination rates by political affiliation, religion, and rural/urban status exceeded racial/ethnic differences (15), suggesting a potential reduction of racial/ethnic disparities in COVID-19 mortality in 2021 relative to those in 2020 .

In the current study, we extend our previous work by estimating the impact of COVID-19 on period life expectancy at birth and at age 65 in 2021 for the total population and for the White, Latino, and Black populations in the US. Estimates are based on provisional data for 2021, accessed as of March 2, 2022 (1).

\section{Methods}

To estimate the impact of COVID-19 on 2021 period life expectancy $\left(e_{x}\right)$ without data on allcause mortality, we employ life table techniques developed to estimate the impact on life expectancy of eliminating one or more causes of death (i.e., cause-deleted life tables) (2). In the present study, we assume that mortality conditions in 2021 would be equivalent to those 
medRxiv preprint doi: https://doi.org/10.1101/2021.10.17.21265117; this version posted March 7, 2022. The copyright holder for this preprint (which was not certified by peer review) is the author/funder, who has granted medRxiv a license to display the preprint in perpetuity.

It is made available under a CC-BY 4.0 International license .

observed pre-pandemic (i.e., had COVID-19 not occurred), and then estimate how the inclusion of COVID-19 deaths alters these mortality conditions. Specifically, we take the pre-pandemic life tables to be cause-deleted life tables in which COVID-19 has been eliminated and recover all-cause life tables for 2021 that incorporate COVID-19 mortality. This strategy has been used in previous studies to estimate the impact of COVID-19 on 2020 life expectancy (3-6).

Provisional COVID-19 deaths by age, race, and ethnicity are provided by the National Center for Health Statistics (NCHS) (1). These data include all deaths for which COVID-19 is listed as an underlying, probable, or presumed cause of death, that had been reported to and processed by the NCHS as of March 2, 2022. Mid-year 2021 population estimates by age, race, and ethnicity are obtained from the US Census Bureau (7). Life tables for 2018 for the total US population and for the non-Latino White, non-Latino Black, and Latino populations are obtained from the NVSS $(8) .^{*}$

We first estimate the expected number of deaths in 2021 in the absence of COVID-19 $\left({ }_{n} \mathrm{D}_{\mathrm{x}}{ }^{*}, 2021\right)$ by multiplying the 2018 age-specific mortality rates $\left({ }_{n} \mathrm{M}_{x, 2018}\right)$ by the 2021 mid-year population for the same age range $\left({ }_{n} K_{x, 2021}\right)$. We then estimate the expected number of deaths in 2021 in the presence of COVID-19 $\left({ }_{n} D_{x, 2021}\right)$ by adding the number of COVID-19 deaths in each age group $\left({ }_{n} \mathrm{COV}_{\mathrm{x}, 2021}\right)$ to the expected number of deaths in each age group from other causes. We assume that individuals who do not die of COVID-19 in 2021 are exposed to the 2018 mortality risks:

$$
\begin{gathered}
{ }_{n} D_{x, 2021}^{*}={ }_{n} M_{x, 2018} *{ }_{n} K_{x, 2021} \\
{ }_{n} D_{x, 2021}={ }_{n} \operatorname{COV}_{x, 2021}+{ }_{n} M_{x, 2018} *\left({ }_{n} K_{x, 2021}-{ }_{n} \operatorname{COV}_{x, 2021}\right)
\end{gathered}
$$

We then calculate the age-specific ratio of expected number of deaths in the absence of COVID19 to expected number of deaths in the presence of COVID-19 $\left({ }_{n} R_{x, 2021}\right)$. Using this ratio and Chiang's method (2), we adjust the 2018 life table values to reflect the presence of COVID-19 mortality and obtain our estimates of all-cause life tables for 2021. We repeat these calculations for each of the racial/ethnic groups in our study.

Because our cause-deleted life table methodology differs from that used by NVSS to estimate 2020 life expectancy, the magnitude of our 2021 estimates will not be directly comparable to the published 2020 life expectancy estimates from NVSS. To facilitate comparisons between 2020 and 2021, we estimate 2020 life expectancy with the same methods as our 2021 calculations, using the provisional counts of COVID-19 deaths (rather than deaths from all causes) provided by NCHS for all of 2020, and mid-year 2020 population estimates provided by the US Census Bureau. $^{+}$

\footnotetext{
* At the time of writing, 2018 was the most recent pre-pandemic year for which life tables were available separately by race and ethnicity.

$\dagger$ These 2020 estimates differ slightly from our previously published estimates (4), because they include additional deaths that were not yet reported to NCHS at the time of the previous analysis, and they use 2020, as opposed to 2019, mid-year population counts.
} 
medRxiv preprint doi: https://doi.org/10.1101/2021.10.17.21265117; this version posted March 7, 2022. The copyright holder for this preprint (which was not certified by peer review) is the author/funder, who has granted medRxiv a license to display the preprint in perpetuity.

It is made available under a CC-BY 4.0 International license .

\section{Results}

Before presenting estimates of life expectancy during the pandemic, we display descriptive statistics of the age-specific COVID-19 mortality rates, which are defined as the number of COVID-19 deaths in an age group in a given year divided by the total population in that age group at the mid-point of the year. Figure 2, which presents age-specific COVID-19 death rates for each of the past two years, portrays a similar time pattern across racial/ethnic groups: a large decline in rates at the oldest ages between 2020 and 2021, with modest changes - often small increases - below age 65 . Figure 3, which shows these rates for the Black and Latino populations divided by the corresponding rates for the White population, highlights the huge decline in relative death rates for the working age population (18-65): COVID-19 death rates at these ages were often three to five times as high in the Black and Latino populations as among Whites in 2020 but roughly twice as high in 2021 . These numbers suggest a substantial decline in racial/ethnic disparities in COVID-19 mortality from 2020 to 2021, but the estimates of life expectancy provided below tell a more nuanced story.

Life expectancy estimates for the total US population and by race/ethnicity are displayed in Table 1. All reductions are relative to 2018 life expectancy values, which are displayed in panel A. Our estimates of 2020 life expectancy reductions due to COVID-19 are displayed in panel B; these are estimated using cause-deleted methods, the same procedure used for the 2021 estimates. To highlight the comparisons between 2020 and 2021, Figure 4 displays the magnitudes of the reductions in life expectancy at birth and at age 65 for 2020 and 2021.

Panel C of Table 1 presents the 2021 estimates, based on the provisional number of COVID-19 deaths in 2021. These estimates indicate that COVID-19 deaths in 2021 imply a 1.7-year reduction in life expectancy at birth and a 1.1-year reduction in life expectancy at age 65 for the total US population relative to pre-pandemic levels. The reductions in life expectancy at birth are largest for the Latino population (3.0 years), followed by the Black population (2.1 years), and smallest for the White population (1.5 years). The 2021 reductions in life expectancy at birth for the total and White populations substantially exceed the reductions estimated for 2020, while those for the Black and Latino populations are similar in the two years.

The estimated reductions in life expectancy at birth for the Latino and Black populations are twice and 1.4 times, respectively, the 1.5-year reduction for Whites. Although these estimates of loss in life expectancy relative to Whites are below those in 2020, they reveal another year of egregious racial/ethnic inequities underlying a huge overall impact of COVID-19 on life expectancy.

\section{Discussion}

With the advent of highly effective vaccines to protect against COVID-19, many in the scientific and public health communities had hoped that the mortality impact of COVID-19 would be substantially lessened in 2021 with period life expectancy returning toward pre-pandemic levels. However, our findings reveal a devasting impact of COVID-19 in 2021, one that is substantially larger than that in 2020. As with our 2020 estimates (4), our results indicate continued racial and ethnic disparities, with the Latino population experiencing the largest reduction in life 
medRxiv preprint doi: https://doi.org/10.1101/2021.10.17.21265117; this version posted March 7, 2022. The copyright holder for this preprint (which was not certified by peer review) is the author/funder, who has granted medRxiv a license to display the preprint in perpetuity.

It is made available under a CC-BY 4.0 International license.

expectancy at birth in 2021 due to COVID-19, approximately one year higher than the Black population. The overall impacts on life expectancy in 2021 will almost certainly be even greater than those shown here because our estimates incorporate deaths from only COVID-19.

The effect of omitting net increases in numbers of deaths from other causes in 2020 is apparent from the National Vital Statistics System (NVSS) estimates for life expectancy, which exceed our estimates for 2020 based only on COVID-19 deaths $(4,9,10)$. These discrepancies with the NVSS estimates for 2020 arise primarily from the unrealistic assumption of independence underlying the cause-deletion procedure: i.e., that the introduction of COVID-19 did not alter the risks of dying from other conditions. A comparison of cause-specific death rates between 2019 and 2020 indicates a net rise in mortality from non-COVID-19 causes in 2020, often referred to as "excess" deaths: increases in several causes (e.g., drug overdoses and other unintentional injuries, homicides, diabetes, heart disease) had a larger overall impact on life expectancy than decreases in other causes (e.g., cancer, Alzheimer's disease, chronic lower respiratory diseases) (9-12). The increase in non-COVID-19 mortality was particularly pronounced in the Black population, leading to a reduction in life expectancy at birth that was one year larger than our estimate based only on COVID-19 deaths $(9,13)$. Given that the risk of COVID-19 fatality is increased in the presence of numerous co-morbidities (e.g., cancer, Alzheimer's disease), mortality rates from some of these chronic diseases may have decreased because severely ill individuals, particularly those with compromised immune systems, succumbed to COVID-19 rather than their underlying condition. Increased mortality rates from non-COVID-19 causes may also have resulted from increased severity of co-morbidities due to COVID-19 infection, delays in primary and preventive care or reduced disease management, and inadequate healthcare due to shortages of equipment, staff, and space (14-17). In addition, increased risks of dying from a broad range of conditions may have been triggered by detrimental changes in health-related behaviors induced by the many social and economic stressors during the pandemic; these behaviors include higher rates of smoking, drinking and drug use; worse nutrition; and reduced exercise (18-20). ${ }^{\ddagger}$ It is possible that the impact of the pandemic on non-COVID-19 mortality was lessened in 2021 as many healthcare facilities resumed close to pre-pandemic levels of operation and some shortages of personnel and supplies were resolved during at least part of the year, but this could have been counteracted by elevated mortality among those who recovered from COVID-19 (23). Finally, misidentification or miscoding of cause of death could have contributed to either increases or decreases in non-COVID-19 causes of death. These errors should have been lower in 2021 than 2020 because of increased availability of COVID-19 diagnostic tests.

Our estimates in Table 1 reveal no difference between the decline in life expectancy at age 65 estimated for the total population in 2021 and that estimated for 2020 - the slightly larger impact for Whites in 2021 is counteracted by smaller declines for the Black and Latino populations. This pattern contrasts with the substantial overall decline in life expectancy at birth in 2021 and

\footnotetext{
\$ Not all of these changes should be attributed to the pandemic, however. In particular, although the pandemic likely resulted in much of the upsurge in drug overdose deaths in 2020 and 2021, drug overdose deaths had been increasing during the years prior to the pandemic (12). Greater availability and use of synthetic opioids in recent years, especially illicitly manufactured fentanyl and fentanyl analogs which are often mixed or used together with other substances and are especially lethal, have led to a greatly enhanced risk of drug overdose $(21,22)$.
} 
medRxiv preprint doi: https://doi.org/10.1101/2021.10.17.21265117; this version posted March 7, 2022. The copyright holder for this preprint (which was not certified by peer review) is the author/funder, who has granted medRxiv a license to display the preprint in perpetuity. It is made available under a CC-BY 4.0 International license .

reflects the shifting distribution of ages at death toward younger ages in 2021 (Figure 1). The younger age distribution of COVID-19 deaths is largely a consequence of the steady increase in the prevalence of vaccination by age, with high levels achieved for the elderly (over $85 \%$ of the 65 and over population fully vaccinated by the end of 2021), in contrast to lower coverage among younger adults (approximately 63\% of adults aged 25-39 fully vaccinated by the end of 2021) (24). High vaccination rates among nursing home residents, who are particularly vulnerable to adverse COVID-19 outcomes, paired with stricter infection protocols, also helped reduce the mortality impact of COVID-19 on older adults in $2021(25,26)$. The net result, as shown in Figure 2, is that mortality from COVID-19 for each racial/ethnic group declined substantially at the oldest ages, particularly for the Black and Latino populations, but changed relatively little at young and middle ages. Although differences between 2020 and 2021 in agespecific death rates at young and middle ages appear small in Figure 2, the modest increases throughout much of this age range, most notable for Whites, have a relatively large impact on life expectancy at birth in 2021.

These results underscore the continued large racial/ethnic disparities in the effect of COVID-19 on life expectancy. The disproportionately high losses of life in the Black and Latino populations reflect the social and economic inequities that have been repeatedly acknowledged throughout the pandemic, most notably high rates of poverty and crowded housing, low income jobs that cannot be performed remotely, a high prevalence of chronic health conditions, and inadequate access to quality healthcare (27-29). Latinos, who once again appear to have suffered the greatest loss of life from COVID-19, have particularly low levels of health insurance coverage, are more likely to live in multigenerational households than most other groups, and often face language barriers to obtaining comprehensible information on viral transmission and mitigation strategies $(28,30-32)$. In addition, Latino workers suffered disproportionate job and income losses during the pandemic because of their overrepresentation in the gig economy and in industries greatly impacted during this period (e.g., construction and leisure and hospitality) and because many Latinos were ineligible for government benefits (33). Although data on race and ethnicity of vaccine recipients are incomplete, existing information suggests that the persistent racial/ethnic disparities are likely partially the result of differences in vaccine uptake early in 2021. For example, after taking differences in age structure into account, Reitsma and colleagues estimate that vaccine uptake rates (for at least one dose) were about $30 \%$ higher in Whites than in the Black and Latino populations through the end of March, 2021, with huge variability across states (34).

It is important to emphasize that, although the estimates of life expectancy reductions in Table 1 indicate some narrowing of the differentials from the previous year, this is entirely due to larger life expectancy reductions in the White population rather than to improvements in either the Black or Latino populations. The recent worsening of COVID-19 mortality among Whites could reflect lower adherence to social distancing and masking guidelines relative to other races/ethnicities $(35,36)$. Although all groups reported high adherence to public health guidelines at the beginning of the pandemic, Whites resumed social activities and ceased maskwearing more quickly than Black and Latino individuals $(35,36)$.

This analysis is subject to several limitations. As previously mentioned, the cause-deleted life table methodology does not account for excess mortality from causes other than COVID-19. 
medRxiv preprint doi: https://doi.org/10.1101/2021.10.17.21265117; this version posted March 7, 2022. The copyright holder for this preprint (which was not certified by peer review) is the author/funder, who has granted medRxiv a license to display the preprint in perpetuity.

It is made available under a CC-BY 4.0 International license .

Moreover, because our estimates for 2021 life expectancy rely on NCHS provisional COVID-19 deaths, which are subject to reporting and processing delays, they are likely to be an underestimate of the impact of COVID-19 on life expectancy.

As period measures, life expectancy estimates for 2021 summarize the mortality conditions of 2021 and do not represent expectations of remaining life for any living cohort, which will depend on future mortality conditions. It is uncertain whether mortality conditions, and thus life expectancy, in 2022 will show a substantial improvement from the past two years. There are several reasons for optimism. The recent expansion of vaccine eligibility to children ages 5 and up should help slow transmission of the SARS-CoV-2 virus in the population, while the administration of booster doses should help protect those most at risk of dying from complications of COVID-19 $(37,38)$. Other efforts that should reduce the mortality impact of COVID-19 are the ongoing development of different types of vaccines, including those targeting new and multiple variants, and of effective oral self-administered antiviral treatments, which can reduce the risk that a COVID-19 infection develops into severe disease (39).

However, there are also many reasons why 2022 may see continued elevated mortality levels and persistent inequities. There is still substantial vaccine refusal in the US, with approximately $15 \%$ of adults not having received any dose of a COVID-19 vaccine by the end of 2021 (24), and vaccine refusal is unlikely to be substantially diminished in the near future. The recent appearance of the easily transmissible Omicron variant has resulted in a huge surge of infections and hospitalizations, although the variant appears to be less fatal than previous ones (40). Still, there is a constant threat of additional variants that, as with Omicron, will be at least partly resistant to existing vaccines and perhaps existing treatments. There is also evidence that survivors of COVID-19 have increased mortality risks for at least six months following initial recovery (41), and the mortality impact of long COVID is not yet known. And, unfortunately, there likely will be other long-term impacts of the pandemic on mortality resulting from the many social, economic, and healthcare disruptions during the past two years that will continue to disproportionately affect vulnerable populations. 
medRxiv preprint doi: https://doi.org/10.1101/2021.10.17.21265117; this version posted March 7, 2022. The copyright holder for this preprint (which was not certified by peer review) is the author/funder, who has granted medRxiv a license to display the preprint in perpetuity.

It is made available under a CC-BY 4.0 International license.

Table 1: Life expectancy estimates and reductions from 2018 for the total US population and by race/ethnicity

\begin{tabular}{|c|c|c|c|c|c|c|c|c|}
\hline & \multicolumn{2}{|c|}{$\begin{array}{c}\text { Total } \\
\text { Population }\end{array}$} & \multicolumn{2}{|c|}{$\begin{array}{c}\text { non-Latino } \\
\text { White }\end{array}$} & \multicolumn{2}{|c|}{$\begin{array}{c}\text { non-Latino } \\
\text { Black }\end{array}$} & \multicolumn{2}{|c|}{ Latino } \\
\hline & Birth & $\begin{array}{l}\text { Age } \\
65\end{array}$ & Birth & $\begin{array}{l}\text { Age } \\
65\end{array}$ & Birth & $\begin{array}{l}\text { Age } \\
65\end{array}$ & Birth & $\begin{array}{c}\text { Age } \\
65\end{array}$ \\
\hline \multicolumn{9}{|c|}{ A) Pre-pandemic } \\
\hline $2018 e_{x}$ & 78.7 & 19.5 & 78.6 & 19.4 & 74.7 & 18.0 & 81.8 & 21.4 \\
\hline
\end{tabular}

\begin{tabular}{|c|c|c|c|c|c|c|c|c|}
\hline \multicolumn{9}{|l|}{ B) 2020 estimates } \\
\hline \multirow{2}{*}{$\begin{array}{l}\text { Number of COVID-19 } \\
\text { deaths } \\
\text { Estimated } 2020 \mathrm{e}_{\mathrm{x}}\end{array}$} & \multicolumn{2}{|c|}{385,463} & \multicolumn{2}{|c|}{232,823} & \multicolumn{2}{|c|}{61,535} & \multicolumn{2}{|c|}{69,472} \\
\hline & 77.4 & 18.4 & 77.7 & 18.5 & 72.8 & 16.5 & 78.9 & 19.3 \\
\hline $\begin{array}{l}\text { Reduction from } 2018 \\
\mathrm{e}_{\mathrm{x}} \text { due to COVID-19 }\end{array}$ & 1.3 & 1.1 & 0.9 & 0.9 & 1.9 & 1.5 & 2.9 & 2.1 \\
\hline
\end{tabular}

\section{C) 2021 estimates}

\begin{tabular}{|l|c|c|c|c|c|c|c|c|}
\hline $\begin{array}{l}\text { Number of COVID-19 } \\
\text { deaths }\end{array}$ & \multicolumn{2}{|c|}{459,991} & \multicolumn{2}{|c|}{303,017} & \multicolumn{2}{|c|}{61,363} & \multicolumn{2}{|c|}{72,981} \\
\hline Estimated 2021 $\mathrm{e}_{\mathrm{x}}$ & 77.0 & 18.4 & 77.1 & 18.4 & 72.6 & 16.8 & 78.8 & 19.6 \\
\hline $\begin{array}{l}\text { Reduction from 2018 } \\
\mathrm{e}_{\mathrm{x}} \text { due to COVID-19 }\end{array}$ & 1.7 & 1.1 & 1.5 & 1.0 & 2.1 & 1.2 & 3.0 & 1.8 \\
\hline
\end{tabular}

Notes: Apart from life expectancy $\left(\mathrm{e}_{\mathrm{x}}\right)$ values from 2018 that are provided by the National Vital Statistics System, all life expectancy estimates are authors' calculations. Estimates for 2020 and 2021 are based on provisional COVID-19 death counts provided by the National Center for Health Statistics (March 2, 2022, update). 
medRxiv preprint doi: https://doi.org/10.1101/2021.10.17.21265117; this version posted March 7, 2022. The copyright holder for this preprint (which was not certified by peer review) is the author/funder, who has granted medRxiv a license to display the preprint in perpetuity.

It is made available under a CC-BY 4.0 International license.

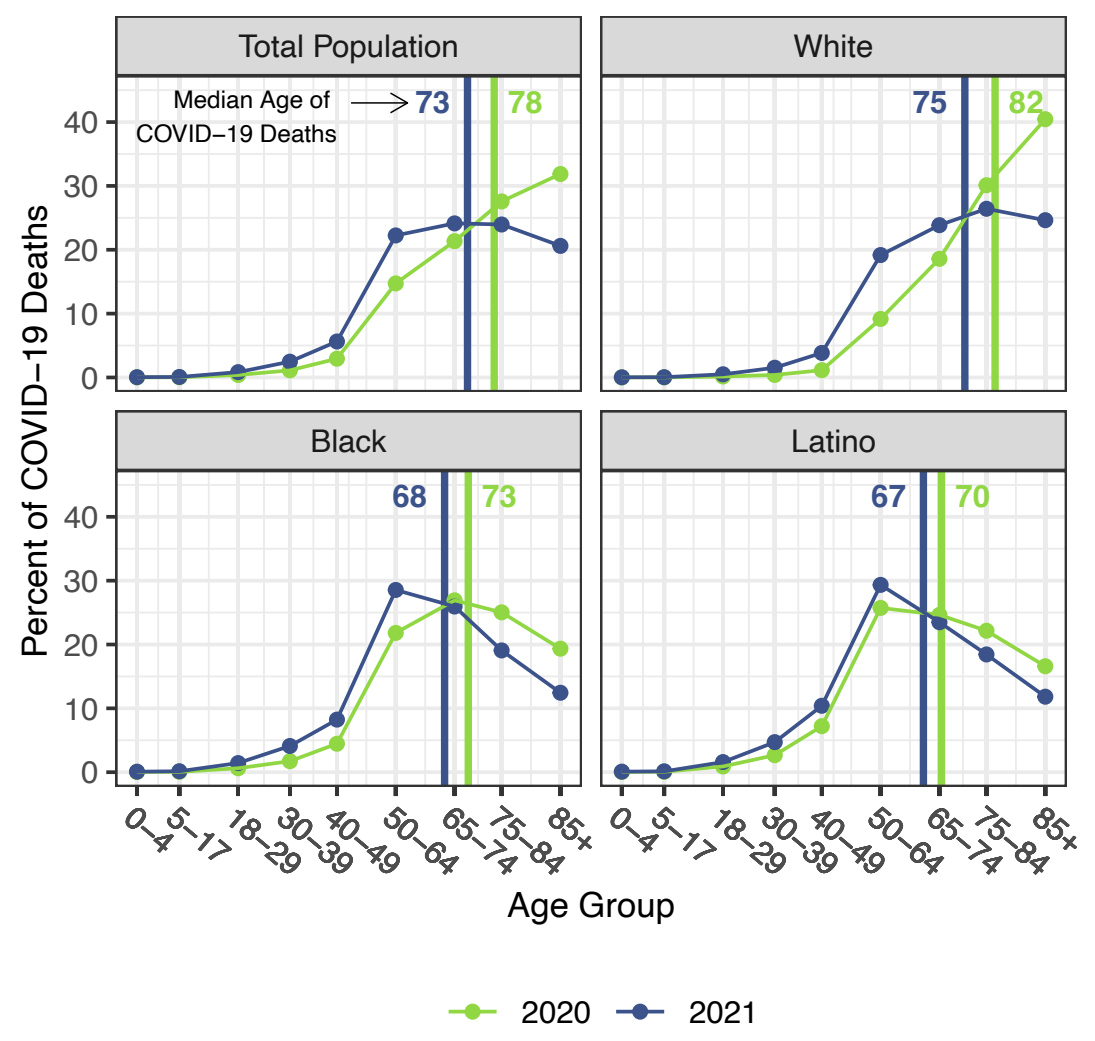

Figure 1. Percentage of COVID-19 deaths in each age group, 2020 and 2021.

Vertical lines indicate the median age of COVID-19 deaths in each year. Data are from provisional COVID-19 deaths provided by the National Center for Health Statistics (March 2, 2022, update). 
medRxiv preprint doi: https://doi.org/10.1101/2021.10.17.21265117; this version posted March 7, 2022. The copyright holder for this preprint (which was not certified by peer review) is the author/funder, who has granted medRxiv a license to display the preprint in perpetuity.

It is made available under a CC-BY 4.0 International license .

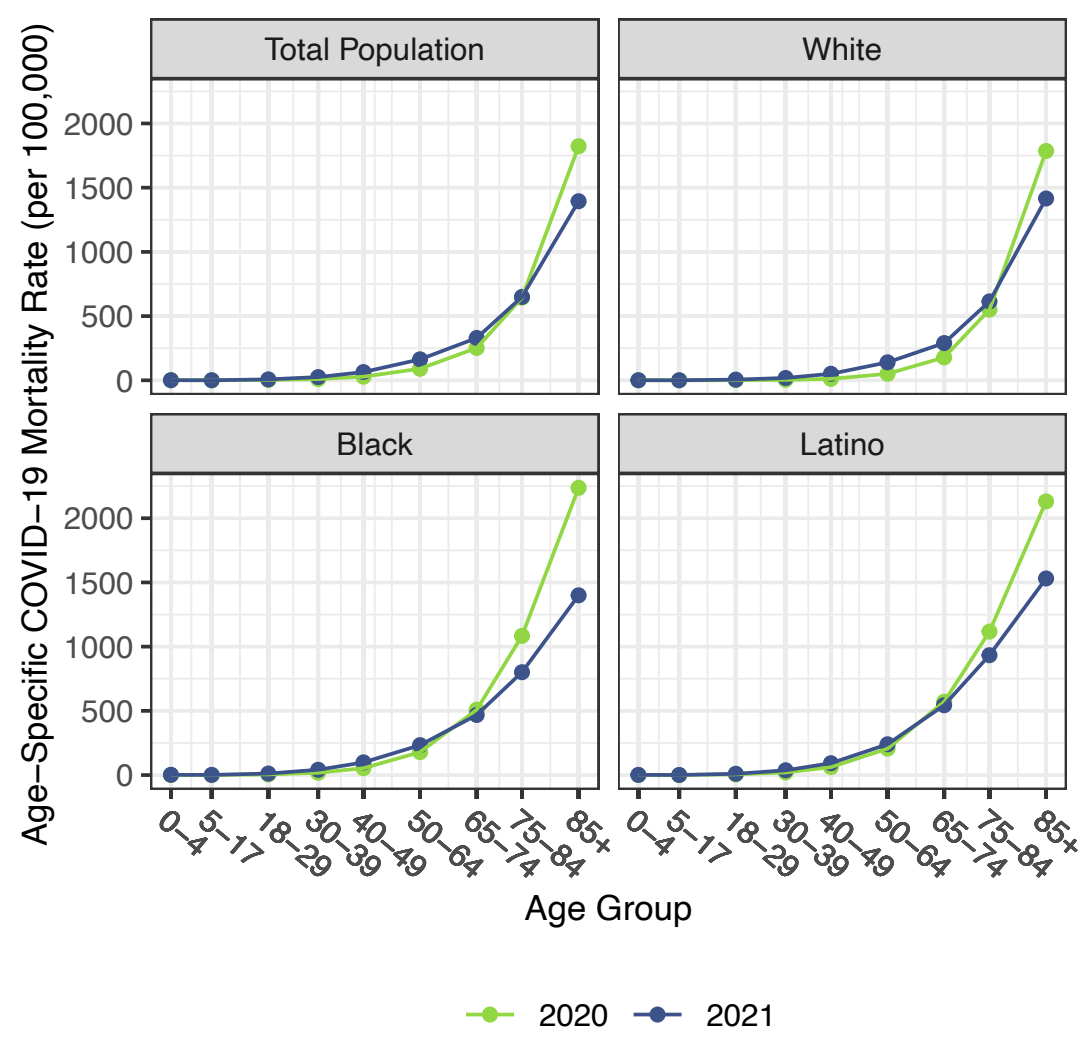

Figure 2. Age-specific COVID-19 mortality rates by race/ethnicity, 2020 and 2021.

Estimates are based on provisional COVID-19 deaths provided by the National Center for Health Statistics (March 2, 2022, update). 


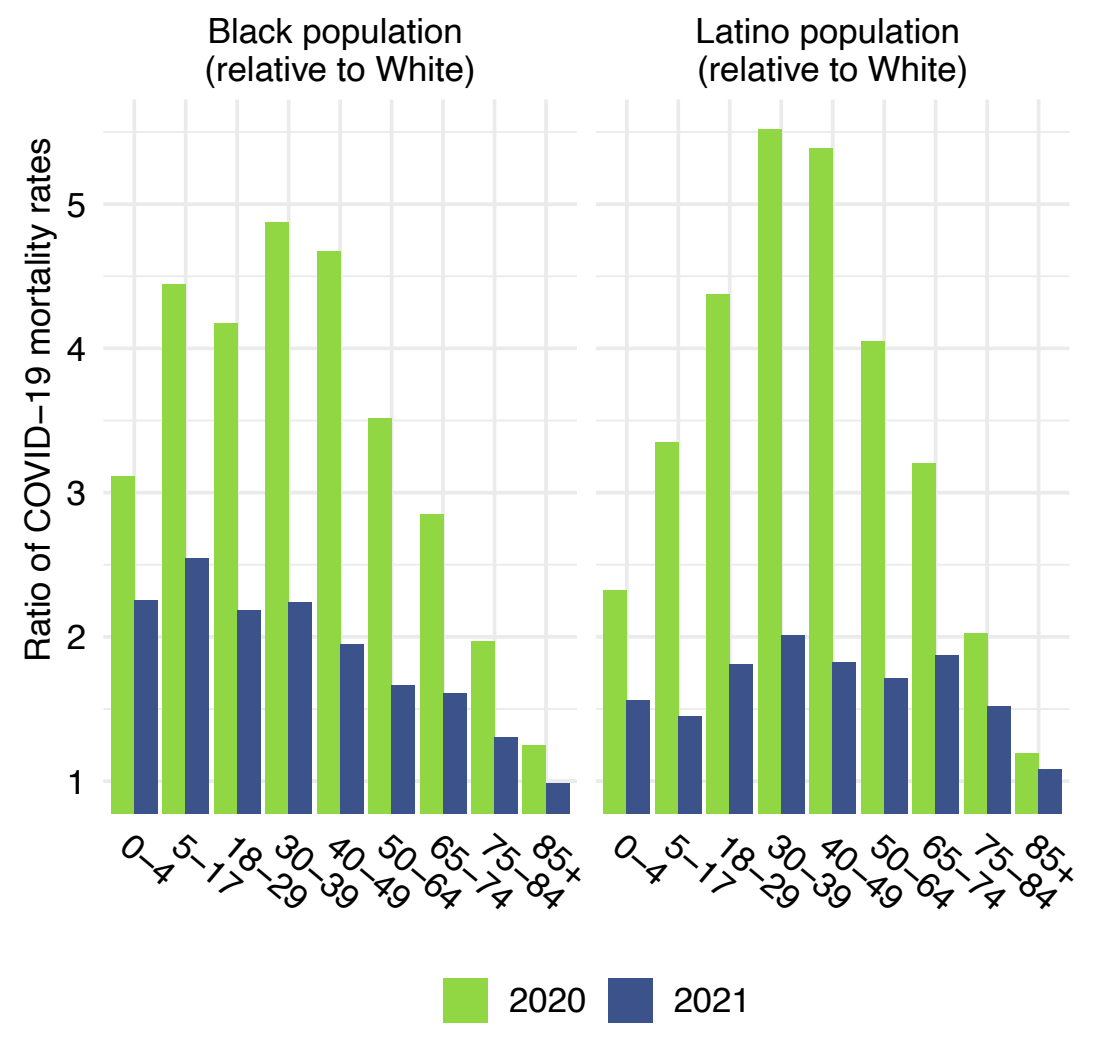

Figure 3. Ratio of age-specific COVID-19 mortality rates relative to the White population, 2020 and 2021. Data are from provisional COVID-19 deaths provided by the National Center for Health Statistics (March 2, 2022, update). 


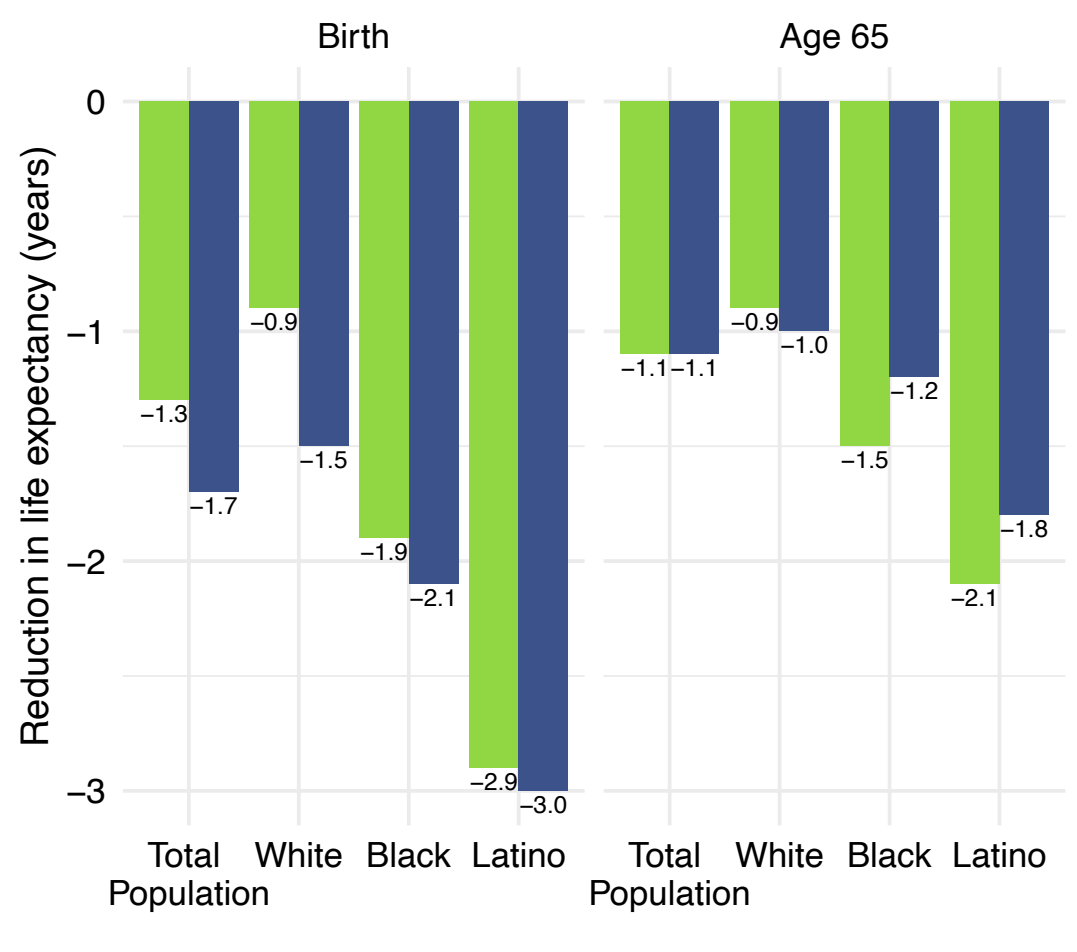

Estimated 2020

Estimated 2021

Figure 4. Reduction in life expectancy at birth and at age 65 (years) due to COVID-19 mortality by race/ethnicity, 2020 and 2021. Changes are all relative to 2018 life expectancy. Data are from provisional COVID-19 deaths provided by the National Center for Health Statistics (March 2, 2022, update). 
medRxiv preprint doi: https://doi.org/10.1101/2021.10.17.21265117; this version posted March 7, 2022. The copyright holder for this preprint (which was not certified by peer review) is the author/funder, who has granted medRxiv a license to display the preprint in perpetuity.

It is made available under a CC-BY 4.0 International license .

\section{Funding}

Research reported in this publication was supported by the National Institute on Aging under Award Number T32AG000037. The content is solely the responsibility of the authors and does not necessarily represent the official views of the National Institutes of Health.

\section{References}

1. NCHS, Provisional COVID-19 Deaths by HHS Region, Race, and Age (2022) (March 2, 2022).

2. CL. Chiang, The life table and its construction. Introd. Stoch. Process. Biostat., 198-214 (1968).

3. T. Andrasfay, N. Goldman, Reductions in 2020 US life expectancy due to COVID-19 and the disproportionate impact on the Black and Latino populations. Proc. Natl. Acad. Sci. 118 (2021).

4. T. Andrasfay, N. Goldman, Association of the COVID-19 Pandemic With Estimated Life Expectancy by Race/Ethnicity in the United States, 2020. JAMA Netw. Open 4, e2114520e2114520 (2021).

5. M. C. Castro, et al., Reduction in life expectancy in Brazil after COVID-19. Nat. Med. 27, 1629-1635 (2021).

6. P. Heuveline, M. Tzen, Beyond deaths per capita: comparative COVID-19 mortality indicators. BMJ Open 11, e042934 (2021).

7. US Census Bureau, Monthly National Population Estimates by Age, Sex, Race, Hispanic Origin, and Population Universe for the United States: April 1, 2010 to December 1, 2020 (with short-term projections to December 2021) (2021) (October 14, 2021).

8. E. Arias, J. Xu, United States Life Tables, 2018 (2020) (January 6, 2021).

9. E. Arias, T.-V. Betzaida, F. Ahmad, K. Kochanek, "Provisional Life Expectancy Estimates for 2020" (National Center for Health Statistics (U.S.), 2021) https:/doi.org/10.15620/cdc:107201 (September 14, 2021).

10. S. L. Murphy, K. Kochanek, J. Xu, E. Arias, "Mortality in the United States, 2020" (National Center for Health Statistics (U.S.), 2021) https:/doi.org/10.15620/cdc:107201 (January 11, 2022).

11. D. A. Glei, "The US Midlife Mortality Crisis Continues: Increased Death Rates from Causes Other Than Covid-19 During 2020” (2021).

12. H. Hedegaard, A. M. Miniño, M. R. Spencer, M. Warner, "Drug Overdose Deaths in the United States, 1999-2020" (National Center for Health Statistics (U.S.), 2021) https:/doi.org/10.15620/cdc:107201 (January 11, 2022). 
medRxiv preprint doi: https://doi.org/10.1101/2021.10.17.21265117; this version posted March 7, 2022. The copyright holder for this preprint (which was not certified by peer review) is the author/funder, who has granted medRxiv a license to display the preprint in perpetuity.

It is made available under a CC-BY 4.0 International license .

13. A. N. Luck, S. H. Preston, I. T. Elo, A. C. Stokes, The unequal burden of the Covid-19 pandemic: Capturing racial/ethnic disparities in US cause-specific mortality. SSM - Popul. Health 17, 101012 (2022).

14. D. Gonzalez, M. Karpman, G. M. Kenney, S. Zuckerman, "Delayed and Forgone Health Care for Nonelderly Adults during the COVID-19 Pandemic" (Urban Institute, 2021).

15. M. É. Czeisler, Delay or Avoidance of Medical Care Because of COVID-19-Related Concerns - United States, June 2020. MMWR Morb. Mortal. Wkly. Rep. 69 (2020).

16. M. L. Ranney, V. Griffeth, A. K. Jha, Critical Supply Shortages - The Need for Ventilators and Personal Protective Equipment during the Covid-19 Pandemic. N. Engl. J. Med. 382, e41 (2020).

17. J. Cohen, Y. van der M. Rodgers, Contributing factors to personal protective equipment shortages during the COVID-19 pandemic. Prev. Med. 141, 106263 (2020).

18. C. P. McDowell, M. P. Herring, J. Lansing, C. Brower, J. D. Meyer, Working From Home and Job Loss Due to the COVID-19 Pandemic Are Associated With Greater Time in Sedentary Behaviors. Front. Public Health 8, 750 (2020).

19. S. Bhutani, M. R. vanDellen, J. A. Cooper, Longitudinal Weight Gain and Related Risk Behaviors during the COVID-19 Pandemic in Adults in the US. Nutrients 13, 671 (2021).

20. X. Zhang, et al., Individual-Level Determinants of Lifestyle Behavioral Changes during COVID-19 Lockdown in the United States: Results of an Online Survey. Int. J. Environ. Res. Public. Health 18, 4364 (2021).

21. G. T. Baldwin, P. Seth, R. K. Noonan, Continued Increases in Overdose Deaths Related to Synthetic Opioids: Implications for Clinical Practice. JAMA 325, 1151-1152 (2021).

22. F. Ahmad, L. Rossen, P. Sutton, "Provisional drug overdose death counts" (National Center for Health Statistics, 2021) (December 14, 2021).

23. A. G. Mainous, B. J. Rooks, V. Wu, F. A. Orlando, COVID-19 Post-acute Sequelae Among Adults: 12 Month Mortality Risk. Front. Med. 8, 2351 (2021).

24. Centers for Disease Control and Prevention, COVID-19 Cases, Deaths, and Trends in the US | CDC COVID Data Tracker. Cent. Dis. Control Prev. (2022) (March 4, 2022).

25. P. Chidambaram, R. Garfield, "Nursing Homes Experienced Steeper Increase In COVID-19 Cases and Deaths in August 2021 Than the Rest of the Country" (Kaiser Family Foundation, 2021) (November 8, 2021).

26. N. V. Resciniti, M. Fuller, J. Sellner, M. C. Lohman, COVID-19 Incidence and Mortality Among Long-Term Care Facility Residents and Staff in South Carolina. J. Am. Med. Dir. Assoc. 22, 2026-2031.e1 (2021). 
medRxiv preprint doi: https://doi.org/10.1101/2021.10.17.21265117; this version posted March 7, 2022. The copyright holder for this preprint (which was not certified by peer review) is the author/funder, who has granted medRxiv a license to display the preprint in perpetuity.

It is made available under a CC-BY 4.0 International license .

27. J. F. Figueroa, et al., Association of race, ethnicity, and community-level factors with COVID-19 cases and deaths across U.S. counties. Healthcare 9, 100495 (2021).

28. N. Goldman, A. R. Pebley, K. Lee, T. Andrasfay, B. Pratt, Racial and ethnic differentials in COVID-19-related job exposures by occupational standing in the US. PLOS ONE 16, e0256085 (2021).

29. S. B. Maness, et al., Social Determinants of Health and Health Disparities: COVID-19 Exposures and Mortality Among African American People in the United States. Public Health Rep. 136, 18-22 (2021).

30. R. Macias Gil, et al., COVID-19 Pandemic: Disparate Health Impact on the Hispanic/Latinx Population in the United States. J. Infect. Dis. 222, 1592-1595 (2020).

31. C. E. Rodriguez-Diaz, et al., Risk for COVID-19 infection and death among Latinos in the United States: examining heterogeneity in transmission dynamics. Ann. Epidemiol. 52, 4653.e2 (2020).

32. A. M. Perry, A. Gelrud Shiro, A. Barr, C. Romer, "Amid the pandemic, Black and Latino men have experienced the largest drop in life expectancy" (The Brookings Institution, 2021) (December 14, 2021).

33. A. Klein, A. Gelrud Shiro, "The COVID-19 recession hit Latino workers hard. Here's what we need to do." (The Brookings Institution, 2020) (December 14, 2021).

34. M. B. Reitsma, J. D. Goldhaber-Fiebert, J. A. Salomon, Quantifying and Benchmarking Disparities in COVID-19 Vaccination Rates by Race and Ethnicity. JAMA Netw. Open 4, e2130343 (2021).

35. B. N. Hearne, M. D. Niño, Understanding How Race, Ethnicity, and Gender Shape MaskWearing Adherence During the COVID-19 Pandemic: Evidence from the COVID Impact Survey. J. Racial Ethn. Health Disparities (2021) https:/doi.org/10.1007/s40615-02000941-1 (December 14, 2021).

36. , Understanding Coronavirus in America | Understanding America Study (December 14, 2021).

37. N. Barda, et al., Effectiveness of a third dose of the BNT162b2 mRNA COVID-19 vaccine for preventing severe outcomes in Israel: an observational study. The Lancet (2021) https:/doi.org/10.1016/S0140-6736(21)02249-2 (November 9, 2021).

38. Centers for Disease Control and Prevention, COVID-19 Vaccines for Children \& Teens. Cent. Dis. Control Prev. (2021) (December 8, 2021).

39. J. Couzin-Frankel, Antiviral pills could change pandemic's course. Science 374, 799-800 (2021). 
medRxiv preprint doi: https://doi.org/10.1101/2021.10.17.21265117; this version posted March 7, 2022. The copyright holder for this preprint (which was not certified by peer review) is the author/funder, who has granted medRxiv a license to display the preprint in perpetuity.

It is made available under a CC-BY 4.0 International license .

40. C. del Rio, S. B. Omer, P. N. Malani, Winter of Omicron-The Evolving COVID-19 Pandemic. JAMA (2021) https:/doi.org/10.1001/jama.2021.24315 (January 10, 2022).

41. Z. Al-Aly, Y. Xie, B. Bowe, High-dimensional characterization of post-acute sequelae of COVID-19. Nature 594, 259-264 (2021). 